

\title{
Motility activation and metabolism characteristics of spermatozoa of the black-lip-pearl oyster Pinctada margaritifera var: cumingii (Jameson, 1901)
}

Marina Demoy-Schneider, A. Levêque, N. Schmitt, M. Pennec, J. Cosson

\section{- To cite this version:}

Marina Demoy-Schneider, A. Levêque, N. Schmitt, M. Pennec, J. Cosson. Motility activation and metabolism characteristics of spermatozoa of the black-lip-pearl oyster Pinctada margaritifera var: cumingii (Jameson, 1901). Theriogenology, 2012, 77 (1), pp.53-64. 10.1016/j.theriogenology.2011.07.014 . hal-01990279

\section{HAL Id: hal-01990279 \\ https://hal.science/hal-01990279}

Submitted on 22 Apr 2020

HAL is a multi-disciplinary open access archive for the deposit and dissemination of scientific research documents, whether they are published or not. The documents may come from teaching and research institutions in France or abroad, or from public or private research centers.
L'archive ouverte pluridisciplinaire HAL, est destinée au dépôt et à la diffusion de documents scientifiques de niveau recherche, publiés ou non, émanant des établissements d'enseignement et de recherche français ou étrangers, des laboratoires publics ou privés. 


\title{
Motility activation and metabolism characteristics of spermatozoa of the black-lip-pearl oyster Pinctada margaritifera var: cumingii (Jameson, 1901)
}

\author{
M. Demoy-Schneider ${ }^{\mathrm{a}, *}$, A. Levêque ${ }^{\mathrm{a}}$, N. Schmitt ${ }^{\mathrm{a}}$, M. Le Pennec ${ }^{\mathrm{a}}, \mathrm{J}_{\text {. Cosson }}^{\mathrm{b}, \mathrm{c}}$ \\ ${ }^{a}$ EA4239, BIOTEM, University of French Polynesia, Tahiti, French Polynesia \\ ${ }^{\mathrm{b}}$ UMR 7009 CNRS, Marine Station, University Paris VI, Villefranche sur Mer, France \\ ${ }^{\mathrm{c}}$ University of South Bohemia in Ceske Budejovice, Faculty of Fisheries and Protection of Waters, South Bohemian Research Center of \\ Aquaculture and Biodiversity of Hydrocenoses, Vodnany, Czech Republic
}

\begin{abstract}
Motility of Pinctada margaritifera (Linnaeus, 1758); var: cumingii (Jameson, 1901) (P. margaritifera) spermatozoa collected from gonads are not immediately activated at spawning in seawater (SW) but motility occurs when spermatozoa are transferred into alkaline seawater ( $\mathrm{pH}$ ranging from 9.0 to 11.4). This motility-activating effect of alkaline $\mathrm{pH}$ is reversed when $\mathrm{pH}$ is shifted back to more acidic values. In both cases, activity of sperm (\% motile cells) increases gradually after alkaline pH activation then lasts for several minutes. The characteristics of these fully motile spermatozoa are described in details at the level of flagella: the wave amplitude and wave-length range 5 to $6 \mu \mathrm{m}$ and $15 \mu \mathrm{m}$ respectively, while the flagellar beat frequency is approximately $49 \mathrm{~Hz}$. The velocity of sperm displacement is from 220 to $230 \mu \mathrm{m} / \mathrm{sec}$. The general swimming pattern is almost circular: the head trajectories describe portions of circles intercalated with small linear segments. Spermatozoa saved in natural seawater at $4^{\circ} \mathrm{C}$ retain potent motility for several days and can be subsequently activated by alkaline seawater. Respiration and ATP concentration were measured in 3 conditions: regular seawater ( $\mathrm{pH}$ 7.8), artificial diluent ( $\mathrm{pH} 8.2$ ), and alkaline Tris-buffered seawater ( $\mathrm{pH}$ 10.5). Results show that sperm respiration rates are higher whereas ATP levels are lower in the latter two media.
\end{abstract}

Keywords: Pearl oyster; Pinctada margaritifera; Sperm quality; Motility parameters; Sperm energetics

\section{Introduction}

In many aquatic species with external fertilization, sperm stored in testis is generally in a nonmotile state and a mechanism must be devised to first, maintain this immotility before maturation and/or shedding in the external medium and second, to allow spermatozoa to

\footnotetext{
* Corresponding author. Tel.: +6898038 29; fax: +689803804. der).
}

become motile when shed from the gonads prior to fertilization. In the case of aquatic animals, two main categories of control mechanisms devised for these tasks have been characterized so far: one category, mainly represented by marine fishes, is using osmolality in combination with specific ions [1], while another category is found in echinoderms (sea urchin) [2], sea cucumbers [3], or in polychaetes (Arenicola marina) [4] where protons (external $\mathrm{pH}$ ) are the main primary controlling agent $[2,4]$. In the latter, it was shown that rise of external $\mathrm{pH}$ entails alkalinization of intraflagel- 
lar $\mathrm{pH}$ which consequently activates the flagellar motors called dyneins [2]. Some intermediate situations are also found: this is the case in ascidians [4] or fishes $[5,6]$ where it was shown that some specific chemicals emanating from eggs constitute a main signal for sperm activation.

As examples of the first instance, many fish species adopted difference of osmolality between seminal fluid and external medium (fresh or seawater depending on species) for controlling motility of their spermatozoa [1]. In a few species such as sturgeons (chondrosteans) [7], the concentration of $\mathrm{K}^{+}$ions is complementary to osmolality in this control mechanism; in the same line, trout sperm motility is also controlled both by osmolality and by $\mathrm{K}^{+}, \mathrm{Ca}^{2+}$ and $\mathrm{Na}^{+}$ion concentration $[1,8]$. More specifically, in rainbow trout (Oncorhynchus mykiss) and in chum salmon (Onchorynchus keta), spermatozoa sampled in the distal portion of the sperm ducts showed $100 \%$ motility while motility was much lower for intratesticular sperm [4]. This suggested a sperm maturation process, which has been so far poorly investigated in male mollusks.

In bivalves, oyster spermatozoa collected by stripping of gonads exhibit poor motility initiated by contact with seawater. In the case of the Japanese oyster Crassostrea gigas, sperm movement is very erratic and forward motility is restricted to a low percentage of the cells in the hour following the activation [9]. One could suppose the same situation occurs in the black-lip-pearl oyster P. margaritifera spermatozoa. In French Polynesia, black pearl production relies almost exclusively on the collection of wild spat of the black-lip-pearl oyster, $P$. margaritifera, which makes aquaculture and marketing highly dependent on natural resources. Hatchery practice was only developed in experimental pearl farms. Spermatozoa were stripped and then visually assessed for their motility activation [10]. Therefore, various conditions attempting to induce full activation of flagellar motility have been tested to obtain a high percentage of motile cells with the aim of obtaining optimal fertilization rates. In the present investigation, we observed that incubation of sperm with alkaline seawater ( $\mathrm{pH} 8.5$ and higher) was efficiently active to induce cell movement; the resulting flagellar waves were similar to those previously observed in sea urchin spermatozoa and able to allow forwardly-directed translation of the majority of sperm cells. This is described as well as general sperm features of this species in the present report. Moreover, metabolic characteristics of bivalve spermatozoa have been little documented. In the case of the oyster $C$. gigas, it has been reported that the ATP content slowly decreased after spermatozoa activation [9]. Variation of respiration rates in bivalves has been described to be dependent on the activation of the spermatozoa [11] and seemed to present variability between species [12]. The present study highlighted that mitochondrial respiration increased in relation to the sperm motility activation and confirmed such variability among different bivalve species.

\section{Materials and methods}

\subsection{Materials}

\subsubsection{Oyster used for sperm collection}

All the experiments were carried out with black-lippearl oysters $P$. margaritifera which were raised in Takapoto atoll, Tuamotu archipelago (French Polynesia, located $560 \mathrm{~km}$ East of Tahiti) until they reached the age of 24 months and an average size $10.65 \pm 0.47$ $\mathrm{cm}$ diameter. They were collected from culture longlines and then transported in a container (room temperature) thanks to a 1-hour flight shipment to the laboratory (University of French Polynesia, Tahiti).

\subsubsection{Sperm collection}

After the two shells were manually opened widely, milt was collected by gonad stripping and carefully removed with a micropipette and the semen ("dry" sperm) was stored in test tubes at $4^{\circ} \mathrm{C} \pm 0.5^{\circ} \mathrm{C}$ before measurements. Semen from different males were never mixed but rather analyzed separately. For most experiments, the measurements were carried out on 51 different males which were sorted out among 7 batches containing $9 \pm 2.6$ males, according to each shipment from the provider. For each sample, the concentration of spermatozoa has been evaluated by counting the cells under magnification $\times 400$, after a 1:2000 dilution using a Malassez's hemocytometer.

\subsubsection{Swimming media}

Two different series of experiments were conducted. In the first one, the sperm of 15 different males had been incubated in different $\mathrm{pH}(6.5,7.5,8.5,9.5,10.5$, and 11.4) media using regular seawater buffered with Tris $50 \mathrm{mmol} / \mathrm{L}$ to adjust final $\mathrm{pH}$ and then observed for the motility activation. In the second experiment, the sperm of 51 different males had been incubated in two activating media: either regular seawater buffered with Tris $50 \mathrm{mmol} / \mathrm{L}(\mathrm{pH} 10.5)$ or a saline solution called DCSB4 (NaCl, $19.5 \mathrm{~g} / \mathrm{L} ;$ glycine, $6.25 \mathrm{~g} / \mathrm{L} ; \mathrm{CaCl}_{2}, 0.15$ $\mathrm{g} / \mathrm{L} ; \mathrm{MgSO}_{4}, 0.19 \mathrm{~g} / \mathrm{L}$; Tris-aminomethane, $2.42 \mathrm{~g} / \mathrm{L}$; adapted from Paniagua-Chavez et al. [13]) which final 




Fig. 1. Swimming spermatozoa of P. margaritifera in alkaline seawater. Records were obtained by stroboscopic illumination combined with dark field microscopy. Left panel: motile spermatozoa at low magnification. Right panel: successive images of a same spermatozoon while swimming (10-ms interval between two frames) in four successive positions (high magnification using a $40 \times$ objective lens). For details about the measurements of the amplitude or length of waves, see [20].

$\mathrm{pH}$ was adjusted to $\mathrm{pH} 8.2$ according to Bougrier and Rabenomanana [14]. As a way of controlling milt quality, spermatozoa were diluted in filtered regular seawater. Twenty-five $\mu \mathrm{L}$ of dry sperm were diluted in $25 \mathrm{~mL}$ of each swimming media. Chemical components were purchased from Fisher Scientific Labosi, (Elancourt, France), VWR-Prolabo (Fontenay sous Bois, France) and Sigma (St Louis, MO, USA).

\subsection{Experimental design}

\subsubsection{Spermatozoa movement}

Movement parameters of spermatozoa and description of their swimming flagella were obtained by use of video recording techniques and stroboscopic illumination. For video records, sperm was diluted 1:100 into regular seawater in a test tube, $0.2 \mu \mathrm{L}$ of this suspension was then transferred into a $50-\mu \mathrm{L}$ drop of swimming medium placed on a glass slide $(\times 25000$ final dilution). Microscopy observations used an Olympus microscope (BH2, Olympus, Japan) 40× D-Apo UVoil 1.30 with diaphragm combined with an Olympus Dark Field oil condenser DWC 1.4-1.2 (Olympus, Japan). Stroboscopic illumination was obtained using a Strobex (Chadwick-Helmuth, El Monte, CA, USA). Video records were performed with a Sony camcorder (Sony s-VHS, SVO-1520, Japan) as previously described by Cosson (2008) [15]. Successive positions of the recorded sperm heads, spermatozoa trajectories, flagellar beat frequency, and velocity were measured from video frames using a video recorder (Sony s-VHS SVO-9500 MDP, Japan) followed by computer digitalization and analyzed by computer assisted sperm anal- ysis (CASA) image analyzer as previously described by Cosson et al. [16,17].

Different flagellar parameters were evaluated. The beat frequency was first measured on 50 different swimming spermatozoa, by adjustment of the strobe frequency, as described by Cosson et al. [18]. The length of flagella, number of curvatures, and amplitude and length of waves were measured on still video images according to the drawing of Figure 1. Because of the beating asymmetry [19], the value of amplitude is resulting from average of the direct and reverse waves [20]. The bend angle was measured as shown in Figure 2 and results represent an averaged value from 50 different sperm cells. The diameter of pseudo circles described by head and the lateral head displacement were measured on photographs according to the example shown in Figure 2.

\subsubsection{Sperm motility}

Twenty-five $\mu \mathrm{L}$ of dry sperm were diluted in $25 \mathrm{~mL}$ of each swimming medium. Then a drop of diluted sperm was placed on a microscope glass slide and qualitative estimates of spermatozoa motility were obtained by continuous visual observation, using light microscopy at magnification $\times 400$, to evaluate the percentage of motile cells according to the scale used by Cosson et al. [16], adapted from Legendre and Billard as following: $\mathrm{MI}=0$ : all spermatozoa are immotile; $\mathrm{MI}=1$ : less than $1 \%$ of spermatozoa are motile; $\mathrm{MI}=2: 1 \%$ to $25 \%$ of spermatozoa are motile; $\mathrm{MI}=3: 25 \%$ to $50 \%$ of spermatozoa are motile; $\mathrm{MI}=$ 4: $50 \%$ to $75 \%$ of spermatozoa are motile; $\mathrm{MI}=5$ : 


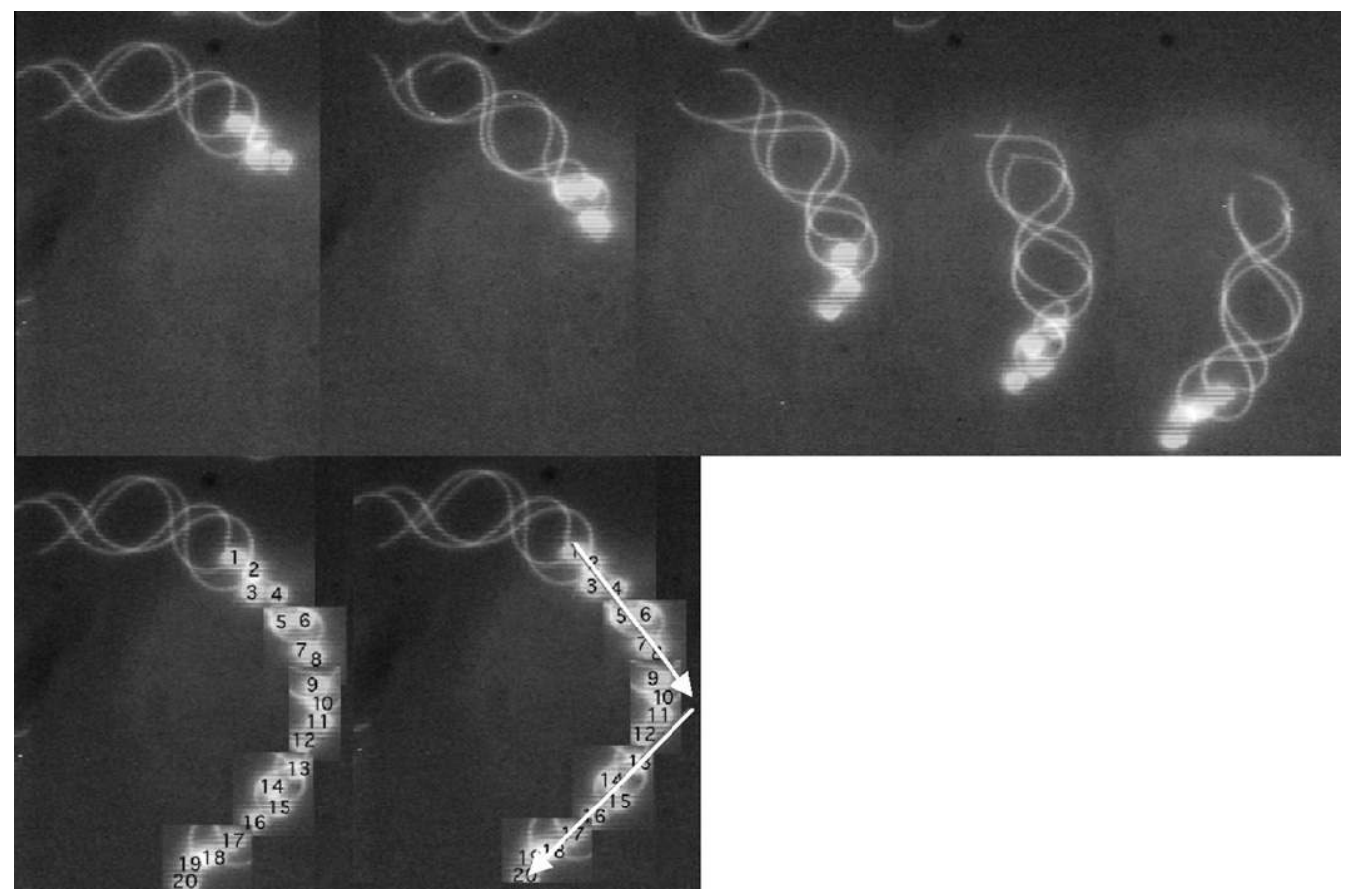

Fig. 2. Fully activated spermatozoa trajectories. Upper panel from left to right shows five successive video frames: each frame received four flashes showing four positions of the same spermatozoon while swimming (interval between two frames was $10 \mathrm{~ms}$ and flash frequency was $100 \mathrm{~Hz}$ ). Lower panel: successive images of the spermatozoon's head position from 1 to 20, while swimming (as above). The head position is followed in the five frames of the upper panel and the overall trajectory of head position is visualized and can be described in the bottom right frame as large circular arcs (white arrow heads) intercalated with transient reorientations (positions 9, 10, and 11). This process is permanently repeated, leading to a broadly circular swimming pattern.

$75 \%$ to $100 \%$ of spermatozoa are motile [21]. To prevent sticking of the spermatozoa to the glass slide, BSA (bovine serum albumin) was added to the swimming medium at the concentration of $0.5 \%$. Alternatively, we also used pluronic acid (F-127 from Sigma, \#P-2443) at $1 \%$ in the swimming solutions. All experiments were performed at $25^{\circ} \mathrm{C}$, temperature at which spawning occurs during the season of reproduction in French Polynesia. The kinetics of motility activation was carried out during $10 \mathrm{~min}$ for each male in both experiments $(\mathrm{N}=15$ in the first experiment and $\mathrm{N}=51$ in the second one).

\subsubsection{Sperm metabolism}

The mitochondrial respiration rates of the sperm suspensions were assessed on 51 different males, by continuous recording of the oxygen concentration in each previously mentioned medium with a highly sensitive and calibrated Clark electrode (Rank Brothers, Cambridge, England) according to Pacey and Bentley [22]. In order to determine the $\mathrm{O}_{2}$ consumption, $50 \mu \mathrm{L}$ of "dry" $P$. margaritifera sperm $\left(15 \times 10^{9}\right.$ spermatozoa per $\mathrm{mL}$ ) was diluted in $1 \mathrm{~mL}$ of the appropriate swim- ming medium leading to a final concentration of $7.5 \times 10^{8}$ spermatozoa per $\mathrm{mL}$ in a tightly closed chamber. The sperm suspension was maintained as homogenous as possible using a magnetic stirrer. This equipment allowed to probe and calculate the oxygen consumption, which was evaluated thanks to a chemical reaction between oxygen, silver anode, and platinum cathode in a liquid sample. A $100 \%$ reading in $\mathrm{O}_{2}$ concentration ( $253 \mathrm{nmol}$ per $\mathrm{mL}$ ) referred to the swimming medium in equilibrium in the air at $25^{\circ} \mathrm{C}$ whereas $0 \%$ of $\mathrm{O}_{2}$ concentration in the swimming medium was obtained after the addition of few crystals of sodium dithionite at the end of the measurement period.

Adenosine 5' triphosphate (ATP) content of the whole sperm was assessed in triplicates for 51 different males and evaluated using bioluminescence (ATPlite-M 1000 assay kit, ref. 6016941, Perkin Elmer Life and Analytical Sciences, Courtaboeuf, France). Evaluation of the ATP content was chosen at 2 min postactivation, according to the results obtained for the sperm motility measurements. Sperm dilution was, according to the manufacturer instructions, ad- 
Table 1

Description of the movement of fully activated spermatozoa in $P$. margaritifera and comparison with sea urchin $P$. miliaris, oyster $O$. commercialis and hake M. merluccius.

\begin{tabular}{|c|c|c|c|c|}
\hline & Pinctada margaritifera & $\begin{array}{c}\text { Sea urchin Psammechinus } \\
\text { miliaris }[47]\end{array}$ & $\begin{array}{c}\text { Oyster Ostrea } \\
\text { commercialis [49] }\end{array}$ & $\begin{array}{c}\text { Hake Merluccius } \\
\text { merluccius }[46]\end{array}$ \\
\hline (1) Length of the flagellum, $\mu \mathrm{m}$ & $47 \pm 2$ & 41 & 43 & $47 \pm 3$ \\
\hline (2) Wave amplitude, $\mu \mathrm{m}$ & $5.4 \pm 0.4$ & 4 & $4-5$ & 4 \\
\hline (3) Wave length, $\mu \mathrm{m}$ & $15.9 \pm 0.7$ & 24 & 26 & 12 \\
\hline (4) Local curvature or bend angle & From -69 to $+65( \pm 4)^{\circ}$ & DND & DND & DND \\
\hline (5) Number of curvatures & $3.1 \pm 0.3$ & DND & DND & 4 \\
\hline (6) Beat frequency, $\mathrm{Hz}$ & $49 \pm 1.5$ & 37 & 43 & 53 \\
\hline (7) Forward velocity, $\mu \mathrm{m} / \mathrm{sec}$ & $221 \pm 12$ & 200 & $163.8 \pm 32.5$ & 180 \\
\hline (8) Waves velocity, $\mu \mathrm{m} / \mathrm{sec}$ & $403 \pm 21$ & DND & DND & DND \\
\hline $\begin{array}{l}\text { (9) Diameter of circular head tracks } \mu \mathrm{m} \\
\text { (see Fig.2) }\end{array}$ & $347 \pm 54$ & DND & DND & DND \\
\hline $\begin{array}{l}\text { (10) Lateral head displacement } \mu \mathrm{m} \\
\text { (see Fig.2) }\end{array}$ & $2.8 \pm 0.3$ & DND & DND & DND \\
\hline
\end{tabular}

DND, data not detailed.

justed to a final concentration of $75.10^{6}$ spermatozoa per $\mathrm{mL}$. Luminescence intensity was obtained by use of a Spectrafluor Plus luminometer (Tecan Group Ltd., Maennedorf, Switzerland) using XFluor4 software (Genios Pro, Tecan Group Ltd., Maennedorf, Switzerland). The emitted light was in direct proportion to the ATP content of the sample; the latter calculated using a standard curve (relative luminescence units [RLU] versus ATP content [nmol per $\mathrm{mL}]$ ).

\subsection{Data analysis}

Regarding the percentage of motile spermatozoa and the activation of sperm motility, a two-way analysis of variance with matched samples was performed. The reported values are mean values $\pm \mathrm{SD} / \mathrm{square} \operatorname{root}(\mathrm{N})$, obtained from the analysis of independent sperm samples. In the case of the respiration rates and ATP content, statistical comparisons were obtained by application of the nonparametric Kruskal-Wallis test.

\section{Results}

\subsection{Spermatozoa movement}

The total volume of dry sperm collected from each stripped animal was sample-dependent and was measured around $1 \pm 0.25 \mathrm{~mL}$. Each sample was counted in triplicate and the mean concentration was estimated at around $15.10^{9}$ spermatozoa per $\mathrm{mL}$. In this species, the total length of the spermatozoon cell was estimated at $49 \pm 2 \mu \mathrm{m}(\mathrm{N}=50)$, among which, the flagellar length represented $47 \pm 2 \mu \mathrm{m}$. An additional terminal (or trailing) filament, about $3 \mu \mathrm{m}$ long, was observed in some spermatozoa (without any consequence on their swimming performance). Mitochondria were visible at the base of the flagellum by light microscopy, localized at the head-tail junction.

$P$. margaritifera oyster spermatozoon movement characteristics could be decribed according to 3 possible behaviors: full activation, "twitching" and "declining".

\subsubsection{Fully activated behavior}

Figure 1 (left part, low magnification) shows that, when sperm motility is highly activated (MI $=4$ or 5 ), spermatozoa present homogeneous characteristics with waves fully developed along flagella and such swimming characteristics last for long periods of time. Figure 1 , left part, highlights that all spermatozoa have a similar flagellar shape. In Figure 1, right part (high magnification), one can observe the flagellar sinusoidal and planar waves of a single spermatozoon, developed from head to flagellar tip. Some sperm movement characteristics of spermatozoa fully activated by contact with alkaline seawater are reported in Table 1: beat frequency ranges 48 to $50 \mathrm{~Hz}$ (beats per sec), wavelength ranges $15.9 \pm 0.7 \mu \mathrm{m}$ and wave amplitude (5 to $6 \mu \mathrm{m})$ is nearly constant along the flagella length. As shown in Figure 2, when successive positions of the head are tracked, one observes that spermatozoa are globally circling but sperm tracks are rather close to a polygonal shape (bottom right). In addition, sperm heads alternate on both sides of the mean track (white arrowheads). Sperm tracks are describing pseudocircles following a clockwise direction for spermatozoa swimming close to the cover slip surface and counterclockwise for cells swimming in the vicinity of glass slide surface. A more detailed observation shows that tracks 




Fig. 3. Kinetics of spermatozoa motility activation in different swimming media as a function of the time period after activation. Values represent mean motility index $\pm \mathrm{SD} /$ square-root $(\mathrm{N})$ for $\mathrm{N}=51$ different males.

describe large arcs alternating with tighter ones giving an image closer to a polygonal shape (bottom right).

\subsubsection{Twitching behavior}

This "twitching" behavior was occurring mainly for spermatozoa observed during a short period immediately after exposure to alkaline seawater, after which they were progressively "half activated" stochastically $(\mathrm{MI}=3)$, then alternatively twitching and stopping several times, and by the end reaching the behavior of "fully activated" spermatozoa as previously described above.

\subsubsection{Declining behavior}

Regarding "declining" spermatozoa, they are observed mostly after exposure to anaerobic conditions (between cover slip and glass slide) and after long-term swimming: motility, in terms of percentage of motile cells, was observed to decline as a function of time $(\mathrm{MI}=2$ to 0 ); from $20 \mathrm{~min}$ or so after activation in alkaline Tris-buffered seawater and later, more and more cells show a "dampening" of their flagellar waves, i.e., presenting distal wave with lower amplitude as compared with proximal, which retained an amplitude with values similar to those observed in the "fully activated" situation described above. Moreover, this modification of waves shape leads to more linear trajectories.

\subsection{Sperm motility}

As shown in Figure 3, P. margaritifera sperm collected by stripping are not activated in regular seawater, but activated in Tris-buffered alkaline seawater $(\mathrm{pH}$ 10.5). The $\mathrm{pH}$ values measured inside the male gonad and in the gonad tract were $6.6 \pm 0.1$ and $7.4 \pm 0.3$ respectively $(\mathrm{N}=10)$. Motility can be initiated by transfer in DCSB4 (pH 8.2) or in Tris-buffered alkaline seawater ( $\mathrm{pH}$ 10.5). Surprisingly, DCSB4, which was initially designed as a stabilizing fish sperm diluent prior to cryoconservation [13], behaved as a motility activator for $P$. margaritifera spermatozoa. When transferred in this activating medium, it takes few min for sperm to reach strong activation after which, spermatozoa remain motile ( $\mathrm{MI}=3$ or 4 ) for more than 10 min. Initiation of the motility using Tris- $\mathrm{Cl}$ at $\mathrm{pH} 10.5$ is faster (about $2 \mathrm{~min}$ ) but duration of high motility $(\mathrm{MI}=4$ or 5$)$ lasts for shorter periods and motility stops at $6 \mathrm{~min}$ or so after activation.

Figure 4 shows the influence of external $\mathrm{pH}$ on spermatozoa motility activation. Thus, the more alkaline the environment, the higher and faster the activation $(\mathrm{P}<$ $0.05)$. When sperm was diluted into Tris-buffered seawater at a lower $\mathrm{pH}$ (6.5), they remained immotile during long periods of time (>10 min). Motility was slowly and incompletely activated when $\mathrm{pH}$ was increased and reached 7.5. From $\mathrm{pH} 8.5$ to 9.5 , spermatozoa were fully motile during the 10-min period following activation. When $\mathrm{pH}$ was very alkaline (10.5 to 11.4$)$, motility rapidly became vigorous $(\mathrm{MI}=4)$ but decreased after a few min following the activation (MI = 2 or 3 ). For sperm motility, it is to be noticed that the data shown are mean values $\pm \mathrm{SD}$ of measurements performed on 51 males 




Fig. 4. Effect of external $\mathrm{pH}$ on spermatozoa motility as a function of the time period after activation. Values represent mean motility index \pm $\mathrm{SD} /$ square-root( $\mathrm{N})$ for $\mathrm{N}=15$ different males.

(Fig. 3) and 15 males (Fig. 4). Due to the high interindividual variability, mean values never reached maximum motility index of 5 .

Moreover, we noticed that high motile sperm (with initial motility index $=5$ ) saved in regular seawater $(\mathrm{pH} 7.8)$ at $4^{\circ} \mathrm{C}$ retained potent motility for several days and can be activated in alkaline $\mathrm{pH}$ seawater. Indeed, spermatozoa can be activated by transfer in seawater buffered with Tris $\mathrm{pH} 10.5$, up to 13 days after collection and conservation at $4^{\circ} \mathrm{C}$. During this storage, they kept their motility behavior and characteristics, even if the motility index progressively declined to 3 (data not detailed).

The main characteristics of fully activated spermatozoa are quantitatively described in Table 1 . The general swimming behavior consists of an asymmetric movement of flagella, similar to that observed for sea urchin spermatozoa and resulting in an approximately circular movement, but more precisely composed of successive arcs as detailed in Figure 2. Heads follow a lateral displacement of small amplitude (Fig. 2). After long periods of motility, some sperm cells show a slight decrease of wave amplitude in the distal part of their flagella, leading to some dampening, which consequently leads to lower swimming velocity. The same occurred in situations where inhibitors were added to the swimming solution.

\subsection{Sperm metabolism}

Respiration rates were measured in the different swimming media: regular seawater ( $\mathrm{pH} 7.8$ ), DCSB4 solution ( $\mathrm{pH} \mathrm{8.2)} \mathrm{and} \mathrm{Tris-buffered} \mathrm{seawater} \mathrm{solution}$
(pH 10.5) (Fig. 5). When P. margaritifera spermatozoa were diluted into regular seawater, oxygen consumption was at very low rate (close to 0). Res-

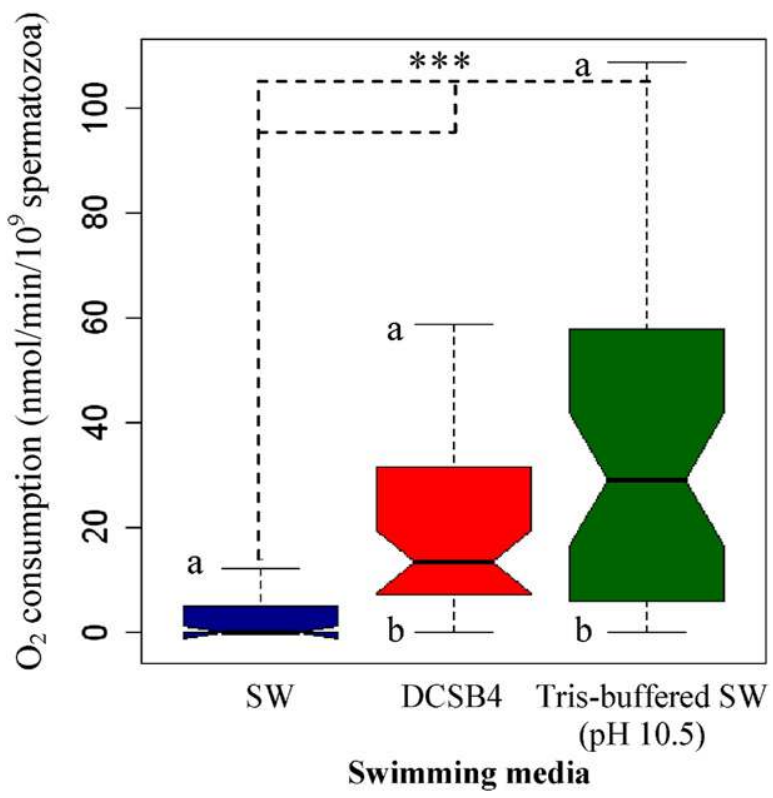

Fig. 5. Influence of ionic composition and external $\mathrm{pH}$ on the spermatozoa respiration rates, 2 min after activation by DCSB4 $(\mathrm{pH} 8.2)$ or Tris-buffered seawater (SW) ( $\mathrm{pH}$ 10.5). Boxes represent median values $\pm \mathrm{SD}$ of oxygen consumption (nmol per min per $10^{9}$ spermatozoa) for 51 different males. "a" letters refer to maximum values and " $b$ " letters refer to minimum values. *** Significantly different results $(\mathrm{P}<0.05)$ between regular SW and activating media (DCSB4 and seawater buffered with Tris $\mathrm{pH} 10.5)$. No significant difference between the two activating media $(\mathrm{P}>0.05)$. 


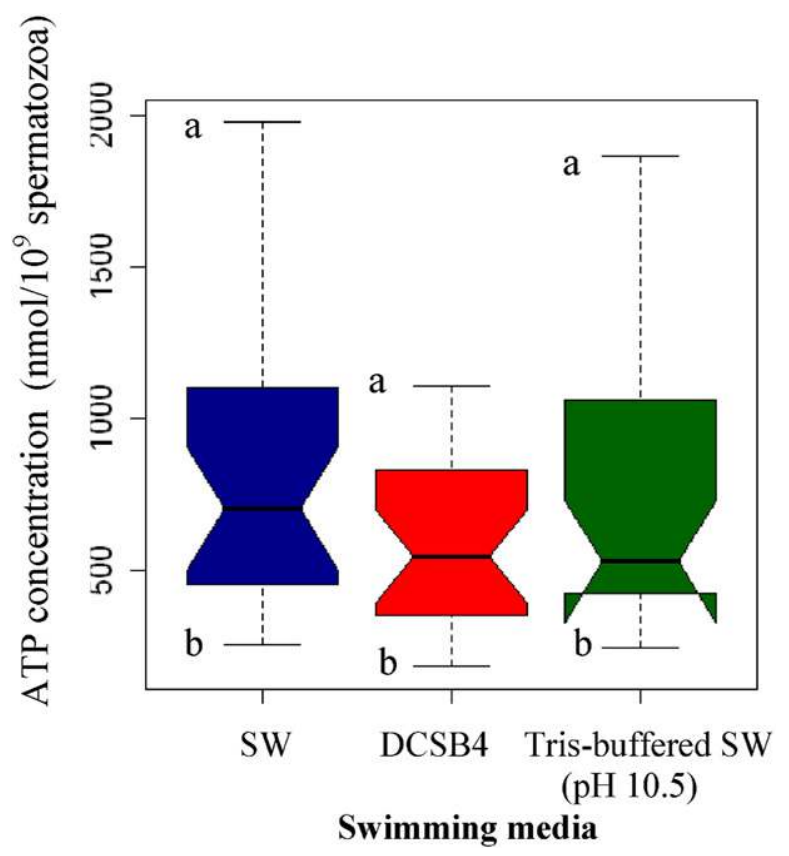

Fig. 6. Influence of ionic composition and external $\mathrm{pH}$ on the ATP content, 2 min after activation by DCSB4 (pH 8.2) or Tris-buffered seawater $(\mathrm{SW})(\mathrm{pH} 10.5)$. Boxes represent median values of oxygen consumption (nmol/109 spermatozoa) for $\mathrm{N}=51$ different males. "a" letters refer to maximum values and "b" letters refer to minimum values. No significant difference between the different swimming media $(\mathrm{P}>0.05)$.

piration rate increased $(\mathrm{P}<0.05)$ when spermatozoa were incubated into more alkaline solutions: median values raised $13.63 \mathrm{nmol}$ per min per $10^{9}$ spermatozoa in DCSB4 and $29.33 \mathrm{nmol}$ per min per $10^{9}$ spermatozoa in seawater buffered with Tris $\mathrm{pH}$ 10.5. No difference was observed between the two activating media $(\mathrm{P}>0.05)$. Moreover, we noticed an important interval between high and low values for DCSB4 (from 0 to $86.46 \mathrm{nmol}$ per min per $10^{9}$ spermatozoa) and seawater buffered with Tris $\mathrm{pH} 10.5$ (0 to $108.76 \mathrm{nmol}$ per min per $10^{9}$ spermatozoa).

Regarding ATP content, all the values were determined using the standard calibration curve with the following parameters $[\mathrm{x}=(\mathrm{y}+198.17) / 387.03$; $\left.R^{2}=0.991\right]$. As shown in Figure 6, median values were respectively $700 \mathrm{nmol}$ per $10^{9}$ spermatozoa in regular seawater, $543 \mathrm{nmol}$ per $10^{9}$ spermatozoa in DCSB4 solution, and $528 \mathrm{nmol}$ per $10^{9}$ spermatozoa, 2 min after activation. Nevertheless, no difference was observed between the different swimming media $(\mathrm{P}>0.05)$. As mentioned above for respiration rates, we noticed an important interval between high and low values: in regular seawater, values varied from
251 to 1977 nmol per $10^{9}$ spermatozoa and for seawater buffered with Tris-Cl pH 10.5, ATP content values varied from 243 to $1868 \mathrm{nmol}$ per $10^{9}$ spermatozoa.

\section{Discussion}

The ability to fertilize an oocyte is assumed to be dependent on the quality of spermatozoa, specifically their motility. In marine species, many biological parameters such as spermatocrit (i.e., the ratio of packed sperm cell volume to semen volume after centrifugation), sperm concentration, swimming characteristics, chemical composition of seminal plasma, enzymatic activity, adenosine-triphosphate (ATP) content, motility, morphology and ultrastructure, membrane integrity, DNA condensation, fertilizing capacity and several others [16,23-37] were generally measured to describe and evaluate sperm quality. Other studies show that, in a few cases, nonmotile spermatozoa can fertilize eggs [38] and large individual variations were reported [39]. All these examples highlight again the limitations of using a single trait to define the quality of the sperm [40]. This explains why we are interested in studying the following criteria to evaluate the quality of $P$. margaritifera spermatozoa: sperm concentration, motility, swimming characteristics, mitochondrial respiration, and ATP consumption.

First of all, when one compares P. margaritifera spermatozoa with other marine species spermatozoa, it appears that they have globally similar characteristics. Therefore, it seems to be conclusive to evaluate the same parameters as those used for other species. Indeed, the supply of sperm of P. margaritifera $\left(15.10^{9}\right.$ spermatozoa per $\mathrm{mL}$ ) is relatively concentrated and falls in the same range as that of sea urchin sperm $\left(26.10^{9}\right.$ spermatozoa per $\left.\mathrm{mL}\right)$ [8] and of many fish species sperm as well $[17,23,41]$. P. margaritifera spermatozoon presents an acrosome [42] as that of sea urchin [43,44] or Japanese oyster Crassostrea gigas [23] while various marine fish species have no acrosome $[16,45,46]$. When the spermatozoon movement characteristics were analyzed, it appeared that $P$. margaritifera spermatozoa develop sinusoidal and planar flagellar waves in a homogeneous fashion when exposed briefly to alkaline seawater.

The general characteristics of flagellar waves of $P$. margaritifera spermatozoa remind in many respects of those of sea urchin sperm flagella $[19,47,48]$ and those of previous results obtained in oyster Ostrea commercialis [49] and fishes [46,50,51]. Briefly, as reported in 
Table 1, for $P$. margaritifera spermatozoa, wave length $(15.9 \pm 0.7 \mu \mathrm{m})$ is lower than for sea urchin Psammechinus miliaris [47] and oyster O. commercialis spermatozoa but higher than for hake Merluccius merluccius [48] spermatozoa. In the case of wave amplitude $(5.4 \pm 0.4 \mu \mathrm{m})$ and velocity, they are higher than for the three compared species. Regarding beat frequency $(49 \pm 1.5 \mathrm{~Hz})$, it is higher for $P$. margaritifera spermatozoa than for sea urchin and oyster $O$. commercialis spermatozoa but lower than for hake spermatozoa. The "twitching" behavior could be compared to the "intermittent" swimming described in sea urchin [52] and in polychaetes [53]. Thus, even if the characteristics of flagellar waves can be compared between different marine species, their detailed values remain species-specific.

Regarding the conditions for activation of motility, it is striking to observe that $P$. margaritifera spermatozoa are immotile $(\mathrm{MI}=0)$ in natural seawater $(\mathrm{pH}$ 7.8), whereas in many other marine species, transfer from seminal fluid into natural seawater is generally enough to trigger high motility as it was shown for fish [5,7,16,51], sea urchin [2], and polychaetes [4]. It was also shown that alkaline $\mathrm{pH}$ (higher than 7.5) activates spermatozoa movement in some marine fish species [8]. It was clearly demonstrated that in sea urchins, sperm activation occurs because of alkalinization of intracellular $\mathrm{pH}$, leading to optimal $\mathrm{pH}$ for dyneinmotor activity [2]. In P. margaritifera spermatozoa, the more alkaline is the $\mathrm{pH}$, the more spermatozoa become active and the faster is the initiation of their motility (Fig. 4), which suggests a similar mechanism. Moreover we observed that activation of motility was slowly reversible, indeed the spermatozoa incubated at acidic $\mathrm{pH}$ remained viable and began to swim normally after subsequent incubation at alkaline $\mathrm{pH}$. Thus we can conclude on the effect of alkaline $\mathrm{pH}$ on the sperm motility activation, the velocity and the intensity of $P$. margaritifera spermatozoa motility activation.

It is important to figure out why $P$. margaritifera spermatozoa activation does not occur right at contact with regular seawater but only when they are submitted to an artificial alkaline medium even though the $\mathrm{pH}$ of natural seawater is already slightly alkaline. These observations may suggest that due to collection of sperm by gonad stripping, all the spermatozoa are not completely mature because some signal delivered by deferent duct would be missing. That could explain why sperm are not motile in natural seawater but only partially why motility is activated in more highly alkaline media. Therefore, one can suggest the existence of a substance that would be delivered in seminal fluid during transit of milt in the male tract when spawning occurs naturally in regular situations; alternatively, such substance could diffuse from the egg and would activate spermatozoa in a way similar to the mechanism previously described in ascidians [6]. In the latter case, a same substance emanating from egg is able both to activate and attract spermatozoa [54]. Another interesting result, described in the present report, concerned the influence of the composition of the swimming medium on the level and the duration of the activation of sperm motility. In addition, we observed that $P$. margaritifera spermatozoa have the ability to retain high motility for 10 min or more. This ability of long-term swimming was previously reported for other marine species especially in invertebrate species. Indeed, according to Faure [55], Suquet et al. [9], or Paniagua-Chavez et al. [13] for the mollusks Pecten maximus, Crassostrea gigas, and Crassostrea virginica respectively, the duration of the spermatozoa motility is generally longer than for marine vertebrate species, such as fish. As reported by Cosson et al. $[16,46]$, in many marine fish species, a large variation was observed between the species studied but the common feature is a restricted duration of the spermatozoa motility (ranging from a few min for halibut, turbot, sea bass, cod, hake, and tuna to 15 to $20 \mathrm{~min}$ for eels and congers). The characteristic quite specific to invertebrate marine species spermatozoa to be motile for a long period of time could be in relation with the strategy of reproduction used by marine invertebrates with low displacement distance, that have to spawn their spermatozoa which thus retain motility for longer before meeting oocytes versus vertebrate species that generally spawn their spermatozoa directly in the closer vicinity of the corresponding oocytes.

In most marine species, such motility activation is correlated with a rapid $\mathrm{O}_{2}$ consumption and may consequently lead to their rapidly running out of their intracellular ATP supply. It is well known that the ability of spermatozoa to get motile is strongly related to the rate of mitochondrial respiration $[2,45,56]$. Respiration rates of activated $P$. margaritifera spermatozoa can be easily measured because of the duration of their motility period, which is long enough to obtain reliable values, whereas in various marine fish species, this period is so brief that it becomes limiting for correct measurement of the respiration rate [15]. The results we obtained (ranging from $0 \mathrm{nmol}$ per min per $10^{9}$ spermatozoa prior activation of the motility [MI $=0$ or 1$]$ to 13.83 after activation in DCSB4 [MI $=3$ or 4$]$ and 
29.33 nmol per min per $10^{9}$ spermatozoa after activation in alkaline Tris-buffered seawater [MI $=4$ or 5$]$ ) can be compared with those mentioned in the literature for Psetta maxima (35 nmol per min per $10^{9}$ spermatozoa prior activation and $125 \mathrm{nmol}$ per min per $10^{9}$ spermatozoa after activation) [37]. Indeed, the values have a three-fold increase and furthermore they show that the respiration rate is strongly increased after motility activation both in turbot and in oyster. Nevertheless, in oyster the values are largely weaker than for sea urchin. Indeed, as reported by Christen et al. [57], in sea urchin, values range from $0.7 \mu \mathrm{mol}$ per min per $10^{9}$ spermatozoa prior to motility activation and $25 \mu \mathrm{mol}$ per min per $10^{9}$ spermatozoa after motility activation. The latter result confirms the large variation of respiration rates among marine species. Moreover our own results showed higher respiration rates when motility was activated in alkaline swimming media. We can conclude that, as for other marine species $[2,22,45,56]$, P. margaritifera spermatozoa motility activation is triggered with an elevation of mitochondrial respiration.

Regarding the ATP content and its consumption during the motility period of spermatozoa, previous studies highlighted an important variation of sperm ATP content among marine species. Indeed for marine invertebrates, such as the sea urchin Strongylocentrotus purpuratus or the Japanese oyster $C$. gigas, the values of ATP content ranged $4.5 \mathrm{nmol}$ per $10^{9}$ spermatozoa and $45 \mathrm{mmol}$ per $10^{9}$ spermatozoa respectively [23,57], whereas, in fishes such as trout or European catfish (Silurus glanis), the values ranged $32.5 \mathrm{nmol}$ per $10^{9}$ spermatozoa and $165 \mathrm{nmol}$ per $10^{9}$ spermatozoa respectively $[23,58]$. Thus, our results confirmed that ATP content appears to be species-specific. Indeed, in most studies regarding most species, the results reported significant variations of ATP stock after motility activation. In sea urchins or in fishes, ATP content decreased very rapidly after activation (i.e., in the first $\mathrm{min}$ ) $[23,45,50]$, whereas in C. gigas, the ATP content decreased more slowly (i.e., in the first $6 \mathrm{~h}$ ) after activation [9]. The ATP values observed for $P$. margaritifera seem to be in accordance with the activation of motility; indeed, the ATP stock is much more rapidly used right after the activation of movement is triggered. According to Figure 3, measurement of the ATP content after a delay of $2 \mathrm{~min}$ after activation appeared to be the best compromise because spermatozoa swam vigorously at this time point after activation in both swimming activation media. Even though the motility duration is longer in DCSB4 as compared with Tris buffered seawater ( $\mathrm{pH}$ 10.5), this does seem to be explained by the amplitude of the ATP store, which remains similar in both situations. Moreover, we observed that the addition of a respiration inhibitor stopped the motility of $P$. margaritifera spermatozoa, thus corroborating that the motility is closely bound to the mitochondrial respiration. Nevertheless, all the results obtained in the present report emphasize an important fluctuation in the respiration rates and ATP values probably corresponding to a large disparity in the sperm samples, due to a large interindividual variability. Moreover, in some samples, we suppose that a large part of spermatozoa are not mature enough and consequently cannot be activated in alkaline swimming media. This variability in the maturity stage could be due to the method of collection of the gametes using gonad stripping, which should be improved.

As a conclusion, the common techniques previously used for other marine species allowed us in the present study to describe sperm motility activation conditions and the metabolism characteristics of spermatozoa of the black-lip-pearl oyster $P$. margaritifera. This study highlighted that $P$. margaritifera spermatozoa present characteristics of movement, motility activation, respiration rates, and ATP utilization similar to that of other marine species, with the exception of fish species, which spermatozoa present a brief motility period $[16,17]$. Complementary studies, such as movement tracking using a computer assisted sperm analysis system [59], analysis of the mechanism of the flagellar movement, evaluation of the role of other energy rich substrates (creatine- or arginine-phosphate) and corresponding activity of enzymes involved in the regeneration of ATP supply (i.e., creatine and arginine kinases) will complement these preliminary observations and provide an overview of the main parameters that allow a better evaluation of the quality of sperm especially regarding predictions on its ability to fertilize, with the aim of selecting the best sperm stocks to create, for this species, a cryobank in a near future.

\section{Acknowledgements}

This work was supported by the French Secretariat d'Etat à l'Outre-mer. Black-lip-pearl oyster P. margaritifera were kindly provided by the Service de la Perliculture of French Polynesia. The ATP concentration measurements were performed in the Laboratoire d'Analyses Médicales of the Centre Hospitalier de la Polynésie Française in French Polynesia.

The authors thank Dr. Marc Suquet (Ifremer, Brest) for his critical and helpful reading, Dr. G. Lecellier 
(Biotem, UPF) and M. Rodiere (UPF) for their help, regarding the statistical analysis.

Thanks to Ifremer Vairao, especially to Dr. G. Le Moullac for our collaboration on the reproduction of the black-lip-pearl oyster $P$. margaritifera.

Thanks also to Dr. L. Musiyan for improving the English in this report.

\section{References}

[1] Alavi SMH, Cosson J. Sperm motility in fishes. (II) Effects of ions and osmolality: a review. Cell Biol Int 2006;30:1-14.

[2] Christen R, Schackmann RW, Shapiro BM. Elevation of the intracellular $\mathrm{pH}$ activates respiration and motility of sperm of the sea urchin Strongylocentrotus purpuratus. J Biol Chem 1982;257:14881-90.

[3] Morita M, Suwa R, Iguchi A, Nakamura M, Shimada K, Sakai $\mathrm{K}$, et al. Ocean acidification reduces sperm flagellar motility in broadcast spawning reef invertebrates. Zygote 2010;18:103-7.

[4] Pacey A, Cosson J, Bentley M. The acquisition of forward motility in the spermatozoa of the polychaete Arenicola marina. J Exp Biol 1994a;19:259-80.

[5] Morisawa S, Morisawa M. Acquisition of potential for sperm motility in rainbow trout and chum salmon. J Exp Biol 1986; 126:89-96.

[6] Yoshida M, Inaba K, Morisawa M. Sperm chemotaxis during the process of fertilization in the ascidians Clona savignyl and Clona intestinalis. Dev Biol 1993;157:497-506.

[7] Cherr GN, Morisawa M, Vines CA, Yoshida K, Smith EH, Matsubara T, et al. Two egg-derived molecules in sperm motility initiation and fertilization in the Pacific herring (Clupea pallasi). Int J Dev Biol 2008;52:743-52.

[8] Alavi SMH, Cosson J. Sperm motility in fishes: (I) Effects of temperature and $\mathrm{pH}$ : a review. Cell Biol Int 2005;29:101-10.

[9] Suquet M, Labbé C, Brizard R, Donval A, Le Coz JR, Quéré C, et al. Changes in motility, ATP content, morphology and fertilisation capacity during the movement phase of tetraploid Pacific oyster (Crassostrea gigas) sperm. Theriogenology 2010; 74:111-7.

[10] Hui B, Vonau V, Moriceau J, Tetumu R, Vanaa V, DemoySchneider M, et al. Hatchery-scale trials using cryopreserved spermatozoa of black-lip pearl oyster (Pinctada margaritifera). Aquatic Living Resources 2011;24:219-23. doi:10.1051/alr/ 2011117.

[11] Akberali HB, Earnshaw MJ, Marriott KR. The action of heavy metals on the gametes of the marine mussel, Mytilus edulis (L.)-I. Copper-induced uncoupling of respiration in the unfertilized egg. Comp Biochem Physiol C 1984;77:289-94.

[12] Suzuki N, Garbers DL. Stimulation of sperm respiration rates by speract and resact at alkaline extracellular $\mathrm{pH}$. Biol Reprod 1984;30:1167-74.

[13] Paniagua-Chavez CG, Buchanan JT, Tiersch TR. Effect of extender solutions and dilution on motility and fertilizing ability of Eastern oyster sperm. J Shellfish Res 1998;17:231-7.

[14] Bougrier S, Rabenomanana LD. Cryopreservation of spermatozoa of the Japanese oyster, Crassostrea gigas. Aquaculture 1986;58:277-80.

[15] Cosson J. Methods to analyse the movements of fish spermatozoa and their flagella. In: Fish Spermatology. Alavi SMH,
Cosson J, Coward K, Raffiee G. (Eds.), Alpha Science International Ltd., 2008, pp. 63-101.

[16] Cosson J, Groison AL, Suquet M, Fauvel C, Dreanno C, Billard R. Studying sperm motility in marine fish: an overview on the state of the art. J Appl Ichthyol 2008a;24:460-86.

[17] Cosson J, Groison AL, Suquet M, Fauvel C, Dreanno C, Billard R. Marine fish spermatozoa: racing ephemeral swimmers. Society for Reproduction and Fertility 2008b;136:277-94.

[18] Cosson MP, Billard R, Gatti JL, Christen R. Rapid and quantitative assessment of trout spermatozoa motility using stroboscopy. Aquaculture 1985;46:71-5.

[19] Gibbons IR. Transient flagellar waveforms in reactivated sea urchin sperm. J Muscle Res Cell Motil 1986;7:245-50.

[20] Brokaw CJ. Nonsinusoidal bending waves of sperm flagella. J Exp Biol 1965;43:155-69.

[21] Legendre M, Billard R. Cryoconservation du sperme de truite arc-en-ciel (Salmo gairdneri R.). Bull Fr Piscic 1980;278: $11-33$.

[22] Pacey A, Bentley M. Agonists of sperm maturation in Arenicola marina (Annelida: Polychaeta) increase the oxygen consumption of sperm suspensions in vitro. Invertebrate Reproduction and Development 1993;24:27-38.

[23] Christen R, Gatti JL, Billard R. Trout sperm motility. The transient movement of trout sperm is related to changes in the concentration of ATP following the reactivation of flagellar movement. Eur J Biochem 1987;166:667-71.

[24] Billard R, Cosson MP. Some problems related to the assessment of sperm motility in freshwater fish. J Exp Zool 1992; 261:122-31.

[25] Ciereszko A, Dabrowski K. Estimation of sperm concentration of rainbow trout, whitefish and yellow perch using spectrophotometric techniques. Aquaculture 1993;109:367-73.

[26] Ciereszko A, Dabrowski K. Relationship between biochemical constituents of fish semen and fertility. The effect of short-term storage. Fish Physiol Biochem 1994;12:357-67.

[27] Billard R, Cosson J, Crim LW, Suquet M. Sperm physiology and quality. In: Broodstock Management and Egg and Larval Quality, Bromage NR, Roberts RJ (Eds.), Blackwell Sciences, Ltd., 1995a, pp. 25-52.

[28] Billard R, Cosson J, Perchec G, Linhart O. Biology of sperm and artificial reproduction in carp. Aquaculture 1995b;129:95112.

[29] Chowdhury I, Joy KP. Seminal vesicle and testis secretions in Heteropneustes fossilis (Bloch): composition and effects on sperm motility and fertilization. Aquaculture 2001;109:367-73.

[30] Lahnsteiner F, Berger B, Weissmann T, Patzner RA. Changes in morphology, physiology, metabolism and fertilisation capacity of rainbow trout semen following cryopreservation. Prog Fish Cult 1996;58:149-59.

[31] Lahnsteiner F, Berger B, Weissmann T, Patzner RA. Evaluation of the semen quality of the rainbow trout (Onchorhynchus mykiss), by sperm motility, seminal plasma parameters and spermatozoa metabolism. Aquaculture 1998;163:163-81.

[32] Fauvel C, Savoye O, Dreanno C, Cosson J, Suquet M. Characteristics of sperm of captive sea bass (Dicentrarchus labrax L.) in relation to its fertilisation potential. J Fish Biol 1998;54:356-69.

[33] Geffen AJ, Evans JP. Sperm trait and fertilisation success of male and sex-reversed female rainbow trout (Onchorhynchus mykiss). Aquaculture 2000;182:61-72. 
[34] Rurangwa E, Kime DE, Ollevier F, Nash JP. The measurement of sperm motility and factors affecting sperm quality in cultured fish. Aquaculture 2004;234:1-28.

[35] Piferrer F, Beaumont A, Falguière JC, Flajshans M, Haffray P, Colombo L. Polyploïd fish and shellfish: production, biology and applications to aquaculture for performance improvement and genetic containment. Aquaculture 2009;293:125-56.

[36] Bobe J, Labbé C. Egg and sperm quality in fish. Gen Comp Endocrinol 2010;165:535-48.

[37] Fauvel C, Suquet M, Cosson J. Evaluation and determination of fish sperm quality. J Appl Ichtyol 2010;26:636-43.

[38] Truscott BR, Idler DR. An improved extender for freezing Atlantic salmon spermatozoa. J Fish Res Board Can 1969;26: 3254-8.

[39] Dreanno C. Régulation de la motilité des spermatozoïdes de turbot (Psetta maxima) et de bar (Dicentrarchus labrax): étude du métabolisme énergétique, du contrôle ionique, de la morphologie et du pouvoir fécondant. PhD thesis, Fac. Vie Santé, University of Rennes France, 1998; pp. 103.

[40] Holt WV, Van Look KJW. Concepts in sperm heterogeneity, sperm selection and sperm competition as biological foundations for laboratory tests of semen quality. Reproduction 2004; 127:527-35.

[41] Suquet M, Dreanno C, Dorange G, Normant Y, Quemener L, Gaignon JL, et al. The ageing phenomenon of turbot spermatozoa: effects on morphology, motility and concentration, intracellular ATP content, fertilisation, and storage capacities. J Fish Biol 1998;52:31-41.

[42] Thielley M, Weppe M, Herbaut C. Ultrastructural study of gametogenesis in the French Polynesian black pearl oyster Pinctada margaritifera (Mollusca Bivalvia) I-Spermatogenesis. J Shellfish Res 1993;12:41-7.

[43] Marks JA, Biermann CH, Walter FE, Kryvi H. Sperm polymorphism within the sea urchin Strongylocentrotus droebachiensis: divergence between pacific and atlantic oceans. Biol Bull 2008; 215:115-25.

[44] Drozdov AL, Vinnikova VV. Morphology of gametes in sea urchins from Peter the Great Bay, Sea of Japan. Ontogenez 2010;41:47-57.

[45] Dreanno C, Cosson J, Suquet M, Dorange G, Fauvel C, Cibert C, et al. Effects of osmolality, morphology and intracellular nucleotid content during the movement of the sea bass (Dicentrarchus labrax) spermatozoa. J Reprod Fertil 1999a;116:113-25.

[46] Cosson J, Groison AL, Fauvel C, Suquet M. Description of hake (Merluccius merluccius) spermatozoa: flagellar wave character- istics and motility parameters in various situations. J Appl Ichthyol 2010;26:644-52.

[47] Gray J. The movement of sea urchin spermatozoa. J Exp Biol 1955;32:775-801.

[48] Woolley DM, Vernon GG. A study of helical and planar waves on sea urchin sperm flagella, with a theory of how they are generated. J Exp Biol 2001;204:1333-45.

[49] Swan MA. The propulsion of nonrotating ram and oyster spermatozoa. Biol Rep 1975;13:17-29.

[50] Alavi SMH, Rodina M, Viveiros AT, Cosson J, Gela D, Boryshpolets $\mathrm{S}$, et al. Effects of osmolality on sperm morphology, motility and flagellar wave parameters in Northern pike (Esox lucius L.). Theriogenology 2009;72:32-43.

[51] Cosson J. Frenetic activation of fish spermatozoa flagella entails short-term motility, portending their precocious decadence. J Fish Biol 2010;76:240-79.

[52] Gibbons BH. Intermittent swimming in live sea urchin sperm. J Cell Biol 1980;84:1-12.

[53] Pacey A, Cosson J, Bentley M. Intermittent swimming in the spermatozoa of the lugworm Arenicola marina (L.) (Annelida: Polychaeta). Cell Motil Cytoskeleton 1994b;29:186-94.

[54] Yoshida M, Yoshida K, Shiba K, Tsuchikawa H, Ootou O, Oishiand $\mathrm{T}$, et al. Ascidian sperm activating and attracting factor: importance of sulfate groups for the activities and implication of its putative receptor. FEBS Lett 2008;582:23-4.

[55] Faure C. Paramètres physiologiques de l'émission et de l'activation des gamètes mâles de deux mollusques bivalves: la coquille Saint Jacques Pecten maximus (L.) et l'huître creuse Crassostrea gigas (Thunberg). $\mathrm{PhD}$ thesis, University of Paris 7, 1996.

[56] Dreanno C, Cosson J, Suquet M, Seguin F, Dorange G, Billard R. Nucleotide content, oxidative phosphorylation, morphology and fertilizing capacity of turbot (Psetta maxima) spermatozoa during the motility period. Mol Reprod Dev 1999b;53:230-43.

[57] Christen R, Schackmann RW, Shapiro BM. Metabolism of sea urchin. Interrelationships between intracellular $\mathrm{pH}$, ATPase activity and mitochondrial respiration. J Biol Chem 1983;258: 5392-9.

[58] Ogier de Baulny B, Labbé C, Maisse G. Membrane integrity, mitochondrial activity, ATP content and motility of the European catfish (Silurus glanis) testicular spermatozoa after freezing with different cryoprotectants. Cryobiology 1999; 39:177-84.

[59] Kime DE, Van Look KJW, Mc Allister BG, Huyskens G, Rurangwa E, Ollevier F. Computer assisted sperm analysis (CASA) as a tool for monitoring sperm quality in fish. Comp Biochem Physiol C Toxicol Pharmacol 2001;130:425-33. 